\title{
The Effect of World Gold Price, World Oil Price, USD/IDR Exchange Rate, and Inflation on the Joint Stock Price Index (JCI) On the Indonesia Stock Exchange (IDX)
}

\author{
Rahmat Hidayat $^{1 *}$, Sudjono \\ ${ }^{1}$ Magister of Management, Universitas Mercu Buana, Jakarta, Indonesia
}

DOI: $10.36348 /$ sb.2022.v08i01.005 $\quad$ | Received: 13.12.2021 | Accepted: 20.01 .2022 | Published: 29.01 .2022

*Corresponding author: Rahmat Hidayat

Magister of Management, Universitas Mercu Buana, Jakarta, Indonesia

\section{Abstract}

This study's purpose is to analyze the impact of world oil prices, world gold prices, inflation, and USD/IDR exchange rates on the Composite Stock Price Index (IHSG) on the Indonesia Stock Exchange (IDX). Secondary data was obtained from the London Financial Market Association (LBMA), Bank Indonesia, and investing.com. The variables used in this study are world oil prices, world gold prices, USD/IDR exchange rates, and inflation as independent variables - also, the Composite Stock Price Index (CSPI) as the dependent variable. This study was conducted using secondary data per month in 2015-2019, non-participant observation with a saturated sampling method of 60 months. The analysis used in this research is Least Square and Autoregressive Moving Average (LS\&ARMA) regression analysis. Simultaneous research results show that world oil prices, gold prices, USD/IDR exchange rates, and inflation significantly affect the Composite Stock Price Index (JCI). The study results partially show that world gold prices and inflation have an important adverse effect on the JCI, while world oil prices significantly positively impact the JCI. It is different from the USD/IDR exchange rate, which does not influence the JCI. The practical conclusion of this research is to afford information to investors that world gold prices, world oil prices, and inflation should be considered in making investment decisions in the capital market.

Keywords: Finance, World Oil Price, World Gold Price, Inflation, USD/IDR Exchange Rate, Composite Stock Price Index (JCI).

Copyright (C) 2022 The Author(s): This is an open-access article distributed under the terms of the Creative Commons Attribution 4.0 International License (CC BY-NC 4.0) which permits unrestricted use, distribution, and reproduction in any medium for non-commercial use provided the original author and source are credited.

\section{INTRODUCTION}

The strain of the trade war between China and the United States raises concerns for countries in the world about the economy's future. The worsening global climate and the impact of the trade war will lead to a slowdown in economic growth. Significant downside risk could lead to a worldwide economic crisis (Haryanto \& Astuti, 2021).

The impact of this global economic slowdown has caused prices and demand for commodities that are the mainstay of Indonesia's exports to decline. Commodity prices recorded a decline, especially crude oil prices triggered by concerns about economic growth and the uncertainty of the trade war between America and China (Haryanto \& Astuti, 2021).
The economic condition can be measured by the movement of the stock price index. If that movement tends to rise, it indicates that the condition of the country is in good condition. Vice versa, if the movement of the stock price index tends to decline, it can be assumed that the country's economic condition is experiencing a decline. Many factors influence the movement of a country's stock price index. However, these factors are classified into two types in general, namely external factors, and internal factors. Internal factors are influenced by the company's financial condition. Meanwhile, external factors that influence are macroeconomic variables, including world oil prices, world gold prices, inflation, and exchange rates (Dewi, 2020) 
The performance of all joint-stock listed on the Indonesia Stock Exchange (IDX) is measured by the JCI value. JCI is an indicator that reflects the performance of capital market developments when they are increasing (bullish) or experiencing a decline (bearish). The movement of the stock price index is an important reference to sell by investors, hold or buy their shares. The movement of the JCI, which continues to increase, indicates Indonesia's capital market development is quite good.

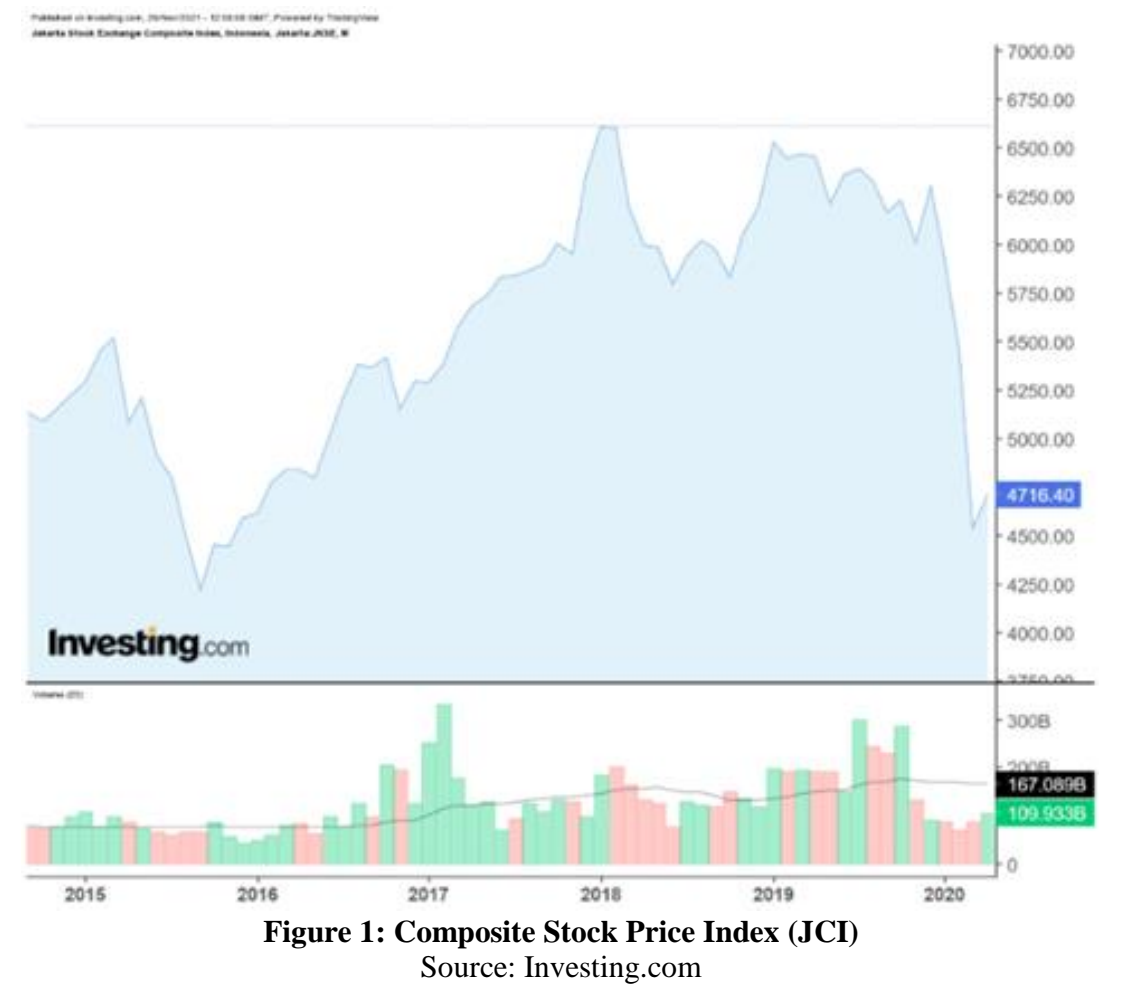

One of the external factors that affect stock price index movement is gold. Gold is a global currency, and its value is universally recognized. The intrinsic value is fixed and standard so that it can be bought and liquidated anywhere. Gold is not affected by inflation (zero inflation), so gold prices always follow the movement of inflation (Husnul et al., 2017). Octavia found that the world gold price had a negative and important effect on the JCI (Purnama et al., 2021). In contrast to Haryanto \& Astuti (2021), Anggriana \& Paramita, and Basit, who found research results that gold prices had no effect on the JCI. (Anggriana \& Paramita, 2020; Basit, 2020; Haryanto \& Astuti, 2021)

Oil is a commodity that is quite important for the economy due to the volatility that constantly follows the economic and political events of a country (Basit, 2020). For oil-exporting countries and companies in the mining sector, increasing world oil prices can benefit because it will attract investors. However, this will result in losses for companies outside the mining sector due to increased operational costs. The increase and decrease in profit have an impact on the stock price of the company, which will ultimately affect the JCI value (Sartika, 2017). The results of research conducted by Beureukat \& Andriani (2021), Novianti \& Perwati (2020), and Oktavia et al. (2018) show that world oil prices have a good and necessary effect on the JCI
(Beureukat \& Andriyani, 2021; Handayani \& Oktavia, 2018; Novianti \& Perwati, 2019). Meanwhile, according to Anggriana \& Paramita (2020), Dewi (2020), Sartika (2017), Fuad \& Yuliadi (2021), and Hersugondo et al., (2019), world oil prices have no influence on the JCI (Anggriana \& Paramita, 2020; Dewi, 2020; Faud \& Yuliadi, 2021; Hersugondo et al., 2019; Sartika, 2017).

Another macroeconomic variable that can have an influence on the JCI is the exchange rate or currency exchange rate. That is the exchange rate of one country's currency unit against another (Bank Indonesia, 2020). Changes in exchange rates will have an influence on investment in the capital market. The increasing price of imported goods was caused by the depreciation of the Indonesian Rupiah against the US dollar. This will increase the manufacturing costs of the company so that companies that use imported raw materials in their production process will experience a decrease in profits. The decline in company profits has an effect on decreasing the interest of investors to invest in the company. Thus, this could affect the development of the JCI. Research by Haryanto \& Astuti (2021), Nurwulandari (2020), Dewi (2020), Fuad \& Yuliadi, Robiyanto, and Oktavia shows that the USD/IDR exchange rate has a bad influence on the JCI. However, the research conducted by Masriyani and Sartika stated 
that the USD/IDR exchange rate not had any effect on the JCI (Dewi, 2020; Fuad \& Yuliadi, 2021; Handayani \& Oktavia, 2018; Haryanto \& Astuti, 2021; Masriyani et al., 2021; Nurwulandari, 2021; Sartika, 2017).

Inflation is a factor that can affect the development of the JCI. Inflation is an economic condition marked by a rapid increase in prices that results in a decrease in purchasing power and is often followed by a reduction in the level of savings and/or investment due to increased public consumption and only a tiny amount for long-term savings (Bank Indonesia, 2020). High inflation will reduce the money's purchasing power and reduce the level of tangible income earned by investors. The increase in inflation gives a negative signal for the capital market investors. The research by Masriyani et al., (2021), Fuad \& Yuliadi (2021), Novianti \& Perwati (2020), and Rosalyn (2018) state that inflation has a negative and significant effect on the JCI (Fuad \& Yuliadi, 2021; Masriyani et al., 2021; Novianti \& Perwati, 2019; Rosalyn, 2018). However, this is not in accordance with the research conducted by Anggriana \& Paramita (2020) and Dewi, which showed that the inflation had no effect on the JCI (Anggriana \& Paramita, 2020; Dewi, 2020).

\section{LITERATURE REVIEW}

Signalling Theory is a solid theoretical foundation because it helps explain decision-making. Amid a large amount of information received, it is very rational that investors usually rely on signals to support their decision-making. Investors react and listen to new news in the market based on the market hypothesis efficiency (Yasar et al., 2020).

Portfolio theory is an investment approach related to the statistical measurement of investors on risk and return expectations. Harry M. Markowitz increase the number of types of support in the portfolio to reduce risk to combine assets into an efficient portfolio diversification. If there is a difference in price movements of the combined assets, it will potentially increase the expected return on investment.

Gold is the most traded precious metal in the world, which plays important role in shaping the macroeconomic a country's conditions, and is used as an investment substitute for global investors. Gold is an important asset and is often seen as a haven and a counter-cyclical investment vehicle. Gold can be defensive in the sense that gold is used as a protectore for investors when the economy is weak, but on the other hand, gold can also be offensive because gold can be used to seek profit through speculation. In many countries, gold is used as a financial standard and also used in electronics and pieces of jewelry. The use of gold in the financial and monetary fields relies on the absolute economic value of gold towards various currencies around the world. Although world commodity markets officially listed gold prices in US Dollars. The use form of gold in the monetary sector is usually in the shape of bars or gold bars in several units of grams to kilograms. In the international commodity market, apart from being traded on the spot market, gold is traded on the futures market too (Robiyanto, 2018).

The world crude oil price is measured from the world oil market. Currently, the benchmark for crude oil prices commonly used is West Texas Intermediate (WTI) or light-sweet. Crude oil traded on there is highquality crude oil. This could happen due to a low sulfur cont $t$ crude oil and it is also very suitable to be used as fuel, so the price is used as a benchmark for world oil trade. The prices of crude oil on WTI are generally five to six US dollars higher than OPEC oil prices. It is also one to two US dollars higher than Brent oil prices. This is the reason why the price of WTI oil has become the oil measurement standard trading in America.

The Rupiah exchange rate is the comparison of the price or value of the Rupiah currency with other currencies in the world. The exchange rate between a country and another is the price level at which residents of the two countries agree to trade with each other. The factors that affect the exchange rate in a country, namely changes in people's tastes, changes in prices of exported and imported goods, increases in general prices (inflation), changes in the rate of return and interest rates on investment (return), and the economic growth of a country (Sartika, 2017). Meanwhile, fluctuations in the USD/IDR exchange rate were caused by several factors, including speculation by foreign exchange traders, the maturity of foreign debt (government or private), the public's lack of confidence in the Rupiah, and most importantly, the weak fundamentals of the Indonesian economy.

Events that tend to push up the price level are called inflationary fluctuations. Inflation is closely cohesive to a decrease in the purchasing power of companies and individuals, which is an important event and is found in almost all countries in the world. Inflation can be caused by two things, namely demandpull and pressure. Demand inflation occurs due to excessive total demand that triggered by a flood of liquidity in the market, resulting in high demand and triggering price level changes. the scarcity of production occurs cost-push inflation, including the shortage of distribution, although demand, in general, has not increased significantly.

\section{HYPOTHESIS}

Supported by previous research results and based on theoretical studies, the hypotheses of this study are as follows: 
Rahmat Hidayat \& Sudjono., Sch Bull, Jan, 2022; 8(1): 33-41

Hypothesis 1: There is a significant negative effect of the World Gold Price (X 1 ) on the Composite Stock Price Index (CSPI) on the Indonesia Stock Exchange (IDX) (Y).

Hypothesis 2: There is a significant positive effect of World Oil Price (X 2 ) on the Composite Stock Price Index (JCI) on the Indonesia Stock Exchange (IDX) (Y).

Hypothesis 3: There is a significant negative effect of the USD/IDR Exchange Rate (X 3 ) on the Composite Stock Price Index (CSPI) on the Indonesia Stock Exchange (IDX) (Y).
Hypothesis 4: There is a significant negative effect of inflation (X 4 ) on the Composite Stock Price Index (CSPI) on the Indonesia Stock Exchange (IDX) (Y).

Hypothesis 5: There is a significant simultaneous effect of World Gold Price (X 1 ), World Oil Price (X 2 ), USD/IDR Exchange Rate (X 3 ), and Inflation (X 4 ) on the Composite Stock Price Index (IHSG) in Indonesia Stock Exchange (IDX) (Y).

The framework of the research is as follows:

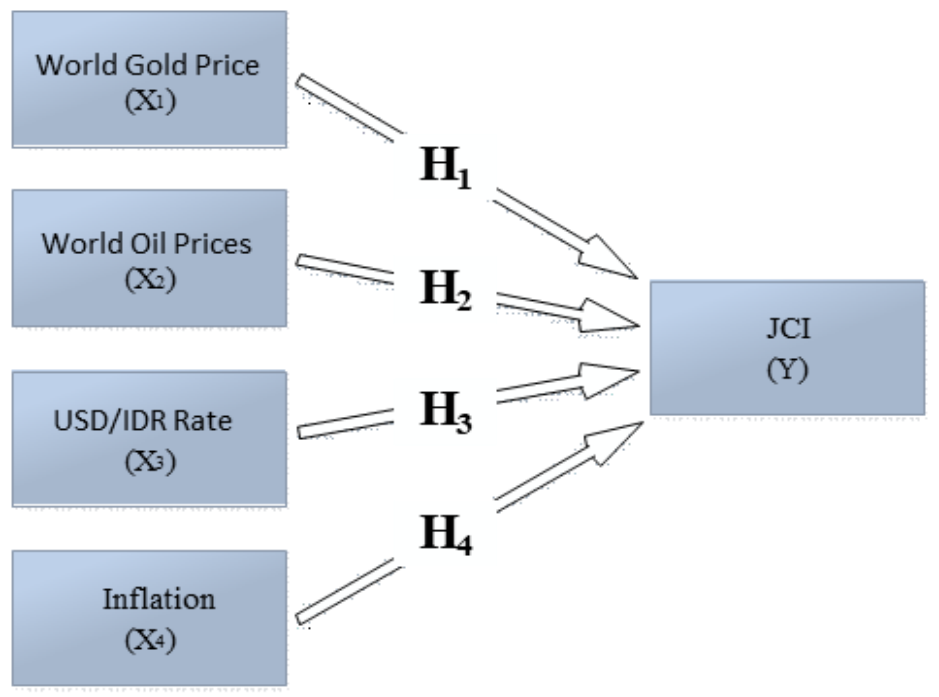

Figure 2: Framework

\section{RESEARCH METHODS}

The research design includes causation research with a quantitative approach. Data analysis in this study used Least Square and Autoregressive Moving Average (LS\&ARMA) regression. Documentation of data collection using non-participant observation. The population used is secondary data of monthly closing price data of the Composite Stock Price Index on the Indonesia Stock Exchange. World gold prices are quoted from the official LBMA website, and world oil prices are quoted from www.investing.com, while data on the USD/IDR exchange rate and inflation are quoted from the official website of Bank Indonesia. The sampling technique used the saturated sample method totaling 60 data throughout the month of observation, namely January 2015 to December 2019 (Bank Indonesia, 2020; Investing, 2021).

\section{RESULTS AND DISCUSSION}

Table-1: Research Variables Descriptive Statistics

\begin{tabular}{|l|l|l|l|l|l|}
\hline $\mathbf{N}$ & $\mathbf{N}$ & Minimum & Maximum & Mean & Std. Deviation \\
\hline JCI & 60 & 4223.91 & 6605.63 & 5628.6923 & 641.61694 \\
\hline World Gold Price & 60 & 1068.25 & 1511.31 & 1265.3803 & 97.82283 \\
\hline World Oil Prices & 60 & 33.62 & 74.15 & 53.4568 & 9.18537 \\
\hline USD/IDR . Rate & 60 & 12625.00 & 15227.00 & 13715.1501 & 542.57283 \\
\hline Inflation & 60 & .0248 & .0726 & .039898 & .0137212 \\
\hline
\end{tabular}

Based on Table 4.1, it can be noticed that 60 research samples obtained a minimum value, namely the inflation variable of 0.0248 . The maximum value, which is the USD/IDR exchange rate variable, is 15227.00. The lowest average value is the inflation variable at 0.039898 , and the highest average value is the USD/IDR exchange rate variable at 13715.1501. The lowest standard deviation is the inflation variable at 0.0137212 , and the highest standard deviation is the JCI variable with a value of 641.61694. The standard deviation of all variables does not have a variety of data because the standard of the deviation < mean. 


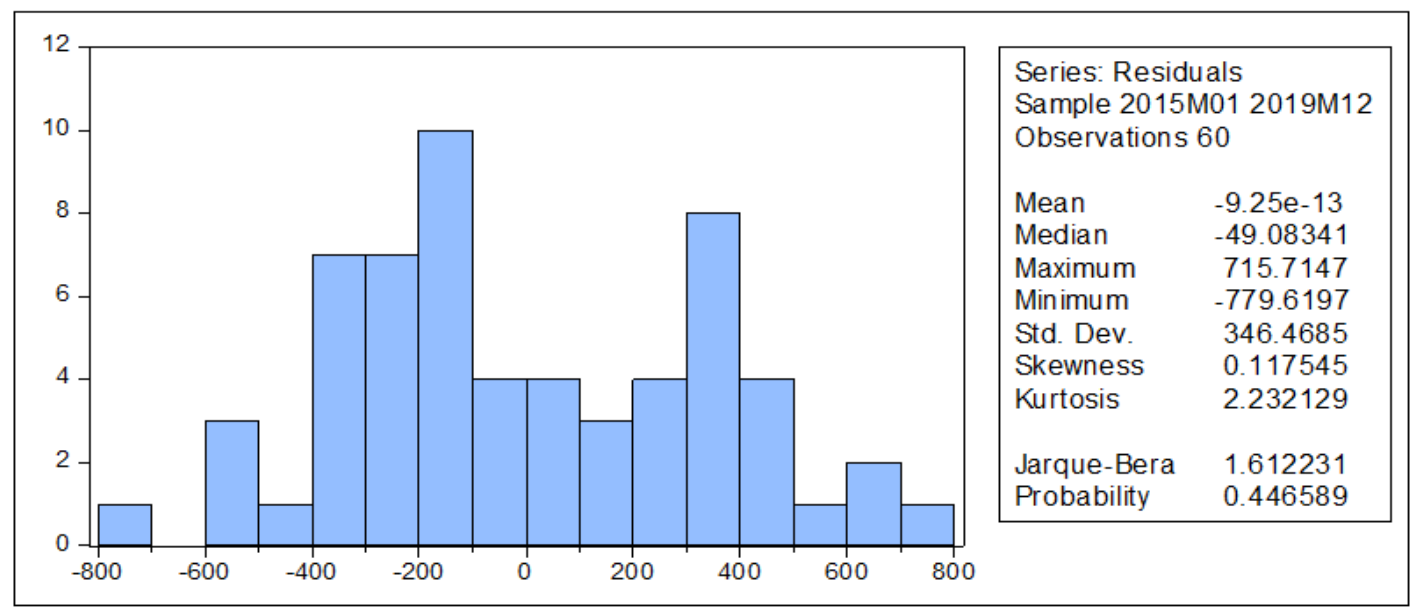

Figure-3: Normality Test Results

The normality test in this study used the bell curve and Kolmogorov-Smirnov (KS) method. The normality test resaults are in Figure 4.1. explained that normally distributed data seen from the form of graphs that were spread evenly (-800 to 800$)$ and almost formed a bell curve. However, these results are very subjective, so the most valid result is the probability value. The data is usually distributed if the probability value is > 0.05 (Hair et al., 2017). The study has a probability value of $0.446589>0.05$; it can be concluded that all the data used were usually distributed.

Table-2. Breusch-Godfrey Serial Correlation LM Test Output

\begin{tabular}{|l|l|l|l|l|}
\hline F-statistic & 80.60686 & \multicolumn{2}{|c|}{ Prob. F(1,54) } & 0.0000 \\
\hline Obs*R-squared & $\mathbf{3 5 . 9 2 9 9 1}$ & \multicolumn{2}{|c|}{ Prob. Chi-Square(1) } & $\mathbf{0 . 0 0 0 0}$ \\
\hline Variable & Coefficient & Std. Error & t-Statistic & Prob. \\
\hline World Gold Price & -0.458609 & 0.374250 & -1.225408 & 0.2257 \\
\hline World Oil Prices & -3.883299 & 3.862515 & -1.005381 & 0.3192 \\
\hline USD/IDR. Rate & -0.008768 & 0.065991 & -0.132860 & 0.8948 \\
\hline Inflation & -3042.845 & 2730.002 & -1.114594 & 0.2700 \\
\hline C & 1025,851 & 1086,709 & 0.943998 & 0.3494 \\
\hline RESID(-1) & $\mathbf{0 . 7 9 6 6 7 8}$ & $\mathbf{0 . 0 8 8 7 3 5}$ & $\mathbf{8 . 9 7 8 1 3 3}$ & $\mathbf{0 . 0 0 0 0}$ \\
\hline
\end{tabular}

Autocorrelation explains that there is no substantial similarity between specific time series. In short, this autocorrelation explains that the data contained in a certain period is not the same. To detect autocorrelation problems, researchers used the method of Breusch-Godfrey Serial Correlation LM Test. That research was identified as having no autocorrelation problem because the Chi-Square(1) and Lagged 1 $(\operatorname{RESID}(-1))$ Probability values $<0.05$.

Table-3: Multicollinearity Test Results

\begin{tabular}{|l|l|l|l|c|}
\hline & $\begin{array}{l}\text { Price } \\
\text { World Gold }\end{array}$ & $\begin{array}{l}\text { Price } \\
\text { World Oil }\end{array}$ & $\begin{array}{l}\text { Exchange rate } \\
\text { USD/IDR }\end{array}$ & Inflation \\
\hline World Gold Price & 1.0000000 & $\mathbf{0 . 3 1 9 0 4 5}$ & $\mathbf{0 . 1 0 9 6 6 4}$ & $\mathbf{- 0 . 5 0 4 7 3 6}$ \\
\hline World Oil Prices & $\mathbf{0 . 3 1 9 0 4 5}$ & 1.0000000 & $\mathbf{0 . 4 5 5 8 3 2}$ & $\mathbf{- 0 . 2 6 3 0 2 7}$ \\
\hline USD/IDR . Rate & $\mathbf{0 . 1 0 9 6 6 4}$ & $\mathbf{0 . 4 5 5 8 3 2}$ & 1.0000000 & $\mathbf{- 0 . 3 6 7 1 7 2}$ \\
\hline Inflation & $\mathbf{- 0 . 5 0 4 7 3 6}$ & $\mathbf{- 0 . 2 6 3 0 2 7}$ & $\mathbf{- 0 . 3 6 7 1 7 2}$ & 1.0000000 \\
\hline
\end{tabular}

Multicollinearity is a situation that shows a strong correlation between two or more independent variables in a regression model. However, regression requires that there should not be a solid correlation between the independent variables because if the relationship is strong (correlation value) $>0.9$, it indicates that the variables are identical or the same. The test results which able to be seen in Table- 3 show that the correlation value is $<0.9$ that means there are no symptoms of multicollinearity. It should be noted that the positive and negative signs in the output above do not indicate a big or small meaning but the direction of the relationship, namely a negative or positive relationship. 
Rahmat Hidayat \& Sudjono., Sch Bull, Jan, 2022; 8(1): 33-41

Table-4: Heteroscedasticity Test Results

\begin{tabular}{|l|l|l|l|l|}
\hline Variable & Coefficient & Std. Error & t-Statistic & Prob. \\
\hline C & 553.6923 & 877.0658 & 0.631301 & $\mathbf{0 . 5 3 0 5}$ \\
\hline World Gold Price & 0.006679 & 0.300892 & 0.022199 & $\mathbf{0 . 9 8 2 4}$ \\
\hline World Oil Prices & -2.304349 & 3.115035 & -0.739750 & $\mathbf{0 . 4 6 2 6}$ \\
\hline USD/IDR . Rate & -0.004570 & 0.053552 & -0.085342 & $\mathbf{0 . 9 3 2 3}$ \\
\hline Inflation & -2110.297 & 2198.484 & -0.959888 & $\mathbf{0 . 3 4 1 3}$ \\
\hline
\end{tabular}

The method used to test heteroscedasticity is the glejser method, which is an analysis to detect heteroscedasticity symptoms through the residual value. When the probability value is significant or sig $<0.05$, then the result rejects $\mathrm{H}_{0}$ (data identified with homoscedasticity) and accepts $\mathrm{H}_{\mathrm{a}}$ (data identified with heteroscedasticity). So to be free from heteroscedasticity, the significance value must be > 0.05 . Due to the test results which can be seen in Table4 , it can be identified that all probabilities are above 0.05 , which means that the heteroscedasticity has no problem in this study.

Table-5: $\mathbf{F}, \mathbf{R}^{2}$, and $t$ test results

\begin{tabular}{|l|l|l|l|l|}
\hline Variable & Coefficient & Std. Error & t-Statistic & Prob. \\
\hline C & 1114.626 & 1690.641 & $\mathbf{0 . 6 5 9 2 9 2}$ & $\mathbf{0 . 5 1 2 5}$ \\
\hline World Gold Price & -2.648166 & 0.580003 & $\mathbf{- 4 . 5 6 5 7 7 6}$ & $\mathbf{0 . 0 0 0 0}$ \\
\hline World Oil Prices & 28.59771 & 6.004574 & $\mathbf{4 . 7 6 2 6 5 4}$ & $\mathbf{0 . 0 0 0 0}$ \\
\hline USD/IDR. Rate & 0.012806 & 0.103226 & $\mathbf{0 . 1 2 4 0 6 2}$ & $\mathbf{0 . 9 0 1 7}$ \\
\hline Inflation & -13565.89 & 4237.820 & $\mathbf{- 3 . 2 0 1 1 4 8}$ & $\mathbf{0 . 0 0 2 3}$ \\
\hline R-squared & $\mathbf{0 . 7 0 8 4 0 8}$ & \multicolumn{2}{|l|}{ Mean dependent var } & 5628.692 \\
\hline Adjusted R-squared & $\mathbf{0 . 6 8 7 2 0 1}$ & \multicolumn{2}{|l|}{ S.D. dependent var } & 641.6169 \\
\hline S.E. of regression & 358.8463 & Akaike info criterion & 14.68332 \\
\hline Sum squared resid & 7082386. & \multicolumn{2}{|l|}{ Schwarz criterion } & 14.85785 \\
\hline Log likelihood & -435.4996 & Hannan-Quinn criter. & 14.75159 \\
\hline F-statistic & $\mathbf{3 3 . 4 0 4 8 9}$ & Durbin-Watson stat & 0.475942 \\
\hline Prob(F-statistic) & $\mathbf{0 . 0 0 0 0 0 0}$ & \multicolumn{4}{|l}{} \\
\hline
\end{tabular}

The simultaneous test is a test of all independent variables' effects on the dependent variable. That affects simultaneously on the dependent variable is significant if $\mathrm{F}_{\text {count }}>\quad \mathrm{F}_{\text {table }}$ or $F$ statistic probability value $<0.05$. So that the first hypothesis (H1 ) in this study is received because all independent variables, namely World Gold Prices, World Oil Prices, USD/IDR Inflation, and exchange rates have a simultaneous or joint effect on the dependent variable, namely the Price Index. Joint Stock (JCI), where $\mathrm{F}_{\text {count }}(33,40489)>\mathrm{F}_{\text {table }}(2.54)$ and $\operatorname{prob}(F$-statistics $)$ $=0.0000<0.05$.

$R$ determination shows how strong the independent variable is in explaining its relationship with the dependent variable. The $R$-value is distributed from 0 to 1 . The independent variable is a strong explanatory factor for the dependent variable if it has a value close to 1 . In this study, the R-squared value is 0.708408 , that means the independent variable used can strongly explain the existence of the dependent variable.

The independent variable has a significant effect if the $t$-statistic value $>\mathrm{t}$-table or probability value $<0.05$. The $\mathrm{t}$-table value for $\mathrm{n}=60$ and $\mathrm{df}(\mathrm{nk})=$ 55 is 1.67303 . The negative and positive signs on the coefficient and t-statistic do not have a big or small meaning but the direction of their influence.

Table-6: Partial Test Results or t Test

\begin{tabular}{|l|l|l|l|l|l|l|}
\hline Variable & Coefficient & Std. Error & t-Statistic & Prob. & & \\
\hline C & 1114.626 & 1690.641 & 0.659292 & 0.5125 & & \\
\hline World Gold Price & -2.648166 & 0.580003 & $\mathbf{- 4 . 5 6 5 7 7 6}$ & $\mathbf{0 . 0 0 0 0}$ & Negative Effect & H2 Accepted \\
\hline World Oil Prices & 28.59771 & 6.004574 & $\mathbf{4 . 7 6 2 6 5 4}$ & $\mathbf{0 . 0 0 0 0}$ & Positive Influence & H3 Accepted \\
\hline USD/IDR. Rate & 0.012806 & 0.103226 & $\mathbf{0 . 1 2 4 0 6 2}$ & $\mathbf{0 . 9 0 1 7}$ & No effect & H4 rejected \\
\hline Inflation & -13565.89 & 4237,820 & $\mathbf{- 3 . 2 0 1 1 4 8}$ & $\mathbf{0 . 0 0 2 3}$ & Negative Effect & H5 Accepted \\
\hline
\end{tabular}

\section{The Effect of World Gold Prices on the JCI}

The world gold price has a significant and negative effect on the Composite Stock Price Index (JCI), meaning that the world gold price and the JCI show the opposite relationship. If the world gold price variable increases, the JCI surely will decrease, and vice versa if the world gold price variable decreases, the JCI will increase. Investing in gold is more interesting to 
investors than stocks when the world gold price increases by selling their shares to switch to gold which causes the JCI to decline. And when the world gold price drops, many investors will sell their gold and switch to stocks so that the JCI will increase. This study is in accordance with another research conducted by Sartika (2017) and Oktavia, which shows the world gold price has a negative effect on the JCI (Oktavia et al., 2018; Sartika, 2017). However, this result is not in line with research that conducted by Haryanto \& Astuti (2021), Anggriana (2020), and Basit (2019), which stated that there is no effect of the world gold price on the Composite Stock Price Index (Anggriana \& Paramita, 2020; Basit, 2020; Haryanto \& Astuti, 2021).

\section{The World Oil Prices Effect on the Composite Stock Price Index (JCI)}

This study proves that world oil prices have a significant and positive effect on the JCI. This means that the higher the world oil price, the higher the JCI. On the other hand, the lower the world oil price, the lower the JCI. The positive and significant world oil prices effect on the JCI occurred because oil prices increase would trigger an increase in the price of mining materials in general which would push up share prices in the mining area. As a result, mining companies have the potential to increase their profits. Because stock trading on the IDX tends to be dominated by stock trading in the mining area, the price increase of these mining stocks will eventually trigger an increase in the JCI. This state is in line with research results conducted by Beureukat \& Andriani (2021), Novianti \& Perwati (2020), and Oktavia et al., (2018) which also shows that world oil prices partially have a significant and positive effect on the JCI (Beureukat \& Andriyani, 2021; Novianti \& Perwati, 2019; Oktavia et al., 2018). However, this is not the same with research conducted by Anggriana \& Paramita (2020), Dewi, Sartika (2017), Fuad \& Yuliadi (2021), and Hersugondo, which states that world oil prices do not have any effect on the Jakarta Composite Index (JCI) (Anggriana \& Paramita, 2020; Dewi, 2020; Fuad \& Yuliadi, 2021; Hersugondo et al., 2019; Sartika, 2017).

\section{The USD/IDR Exchange Rate Effect on the Composite Stock Price Index (IHSG)}

The USD/IDR exchange rate does not have any effect on the JCI. The study is not in line with the Signaling Theory that states the USD/IDR exchange rate has an effect on the JCI. Starting from the end of the third quarter of 2015 until 2019, the JCI tended to rise significantly. In the midst of the dynamics of the Fed Fund Rate rising and unstable oil prices, the USD/IDR exchange rate was not a factor influencing the JCI movement, but a tax amnesty which was considered capable of protecting the strengthening of the JCI which was originally in the position of 4,223.91, later at the end of 2017 was in position 6,355.65. In addition, the strengthening of the JCI, especially in
2017 was the impact of fairly low inflation maintained in the 3-4\% range, relatively low-interest rates, and a fairly good political climate (Kontan, 2017). JCI had experienced a decline to $5,799.24$, but then rose again to $6,299.54$ at the end of 2019 due to the inflow of funds from foreign investors (OJK, 2019). These study results are in line with the research by Masriyani et al., (2021) and Sartika (2017) that state the USD/IDR exchange rate has no effect on the JCI (Masriyani et al., 2021; Sartika, 2017). However, this is not the same with research by Haryanto \& Astuti (2021), Nurwulandari (2020), Dewi (2020), Fuad \& Yuliadi (2021), Robiyanto (2018), and Oktavia et al., (2018) that shows the USD/IDR exchange rate has a negative effect on the JCI (Dewi, 2020; Fuad \& Yuliadi, 2021; Haryanto \& Astuti, 2021; Nurwulandari, 2021; Oktavia et al., 2018; Robiyanto, 2018).

\section{The Effect of Inflation on the Composite Stock Price Index (JCI) \\ Inflation has a significant and negative impact} on the JCI. A high increase in inflation is able to reduce the level of real income that investors get from their investments. On the other hand, if the inflation rate decreases in any country, this will be a good signal for investors as the risk of purchasing power of money decreases and also the risk of legit income declines. This study results support the research by Masriyani et al., (2021), Fuad \& Yuliadi (2021), Novianti \& Perwati (2020), and Rosalyn (2018) which reveal that inflation has a significant and negative effect on the JCI (Fuad \& Yuliadi, 2021; Masriyani et al., 2021; Novianti \& Perwati, 2019; Rosalyn, 2018). However, this is not in line with research by (Anggriana, 2020) and (Dewi, 2020) which stated that inflation had no effect on the JCI (Anggriana \& Paramita, 2020; Dewi, 2020).

\section{CONCLUSIONS AND SUGGESTION \\ Based on the results of the discussion and analysis, it} can be concluded that:

1. The world gold price has a significant and negative effect on the Composite Stock Price Index. This can be noticed from the t-statistic of 4.565776 (the negative sign is ignored) which is greater than the t-table of 1.67303 with a significance of 0.0000 which is smaller than 0.05 , so the second hypothesis $\left(\mathrm{H}_{2}\right)$ shows that the world gold price has an influence on the Composite Stock Price Index is acceptable.

2. World oil prices have a significant and positive effect on the Composite Stock Price Index. The significance value that is smaller than the expected significance value $(0.05)$ indicates that the variable of world oil price has an influence on the JCI, so the third hypothesis (H3) proposed is accepted. Thus, world oil prices can be used to predict the JCI. 
Rahmat Hidayat \& Sudjono., Sch Bull, Jan, 2022; 8(1): 33-41

3. The USD/IDR exchange rate does not have any effect on the Jakarta Composite Index (JCI). This means that any decrease or increase in the USD/IDR exchange rate does not affect the JCI. The empirical findings of this study are not in accordance with the fourth hypothesis ( $\mathrm{H} 4$, which shows that the USD/IDR exchange rate variable has a negative effect on the JCI. Therefore, the fourth hypothesis (H4) is rejected.

4. Inflation has a negative and significant impact on the JIC. This means that if inflation in Indonesia increases, the movement of the JCI value will decrease, and vice versa. These study results are in accordance with the fifth hypothesis $\left(\mathrm{H}_{5}\right)$ which states that the inflation variable has a negative influence on the JCI. Thus, the fifth hypothesis $\left(\mathrm{H}_{5}\right)$ is accepted.

5. The test results simultaneously (simultaneously) are in line with the first hypothesis (H1) which shows that there is a significant effect of world gold prices, world oil prices, USD/IDR exchange rates, and inflation on the JCI. Therefore, the first hypothesis $\left(\mathrm{H}_{1}\right)$ can be accepted.

6. The determination coefficient test result can be noticed that the Adjusted $\mathrm{R}$-squared value is 0.687201 , which means that the ability of the regression model consisting of world oil prices, world gold prices, USD/IDR exchange rates, and inflation as independent variables is able to explain variations in the index. The JCI as the dependent variable is $68.72 \%$. The remaining $31.28 \%$ was caused by other variables that not examined in this study.

Based on the research conclusions that have been described, some suggestions can be made as follows:

1. For investors who wish to invest in stocks, it is advisable to pay more attention to information related to world gold prices, world oil prices, and inflation as material for consideration in making investment decisions. This is due to the results of the analysis proving that the three variables affect the JCI significantly.

2. Gold can be used as an alternative investment as an emergency reserve fund, especially if the stock market is in a bad condition. So that at any time the company/investor needs funds quickly, it can be obtained through gold investment.

3. For further researchers, it is expected to use more macroeconomic variables in order to be able to obtain better results. In addition, it is also recommended to add a term of research time for obtaining results that are closer to the actual conditions and to get a better description of the capital market condition in Indonesia.

\section{REFERENCES}

- Anggriana, R. S., \& Paramita, R. S. (2020). Analisis Pengaruh BI Rate, Kurs, Inflasi, Harga
Minyak, dan Harga Emas Dunia terhadap Indeks Harga Saham Gabungan Periode 2016-2019. Jurnal Ilmu Manajemen, 8(3), 1085-1098.

- Bank Indonesia. (2020). Bank Indonesia. https://www.bi.go.id/

- Basit, A. (2020). Pengaruh Harga Emas dan Minyak Dunia Terhadap Indeks Harga Saham Gabungan (IHSG) Periode 2016-2019. Jurnal Aplikasi Akuntansi, 5(1), 42-51.

- Beureukat, B., \& Andriyani, E. Y. (2021). Pengaruh Harga Minyak Dunia, Indeks Dow Jones dan Indeks Hang Seng Terhadap Indeks Harga Saham Gabungan Periode 2016-2020. Oikonomia Jurnal Manajemen, 17(1).

- Dewi, I. P. (2020). Pengaruh Inflasi, Kurs, dan Harga Minyak Dunia terhadap Indeks Harga Saham Gabungan di Bursa Efek Indonesia. Jurnal Ilmu Manajemen, 17(1), 10-19.

- Fuad, F., \& Yuliadi, I. (2021). Determinants of the Composite Stock Price Index (IHSG) on the Indonesia Stock Exchange. Journal of Economics Research and Social Sciences, 5(1), 27-41.

- Hair, J. F., Matthews, L. M., Matthews, R. L., \& Sarstedt, M. (2017). PLS-SEM or CB-SEM: updated guidelines on which method to use "PLSSEM or CB-SEM: updated guidelines on which method to use." Organizational Research Methods, MIS Quarterly, and International Journal, 1(2), 107-123.

- Handayani, W., \& Oktavia, S. (2018). Effect of Rupiah Exchange Rate, GDP Growth, and Dow Jones Index on Composite Stock Price Index in Indonesia Stock Exchange. Journal of Accounting and Strategic Finance, 1(01), 23-32. https://doi.org/10.33005/jasf.v1i01.24

- Haryanto, H., \& Astuti, S. (2021). Analisis Pengaruh Nilai Kurs Dolar, Harga Emas Dunia, Dow Jones, Tingkat Suku Bunga Terhadap Indeks Harga Saham Gabungan. Jurnal Ilmiah Mahasiswa Manajemen Bisnis Dan Akuntansi (JIMMBA), 3(1), 113-123.

- Hersugondo, H., Dhani Laksana, R., \& Mayasari, V. (2019). Analiysis Effect of Commodities Crude Oil and Coal in Indonesia Stock Exchange. Performance, 26(2), 143-152.

- Husnul, H. M., Hidayat, R. R., \& Sulasmiyati, S. (2017). Analisis pengaruh inflasi, kurs (IDRUSD), produk domestik bruto dan harga emas dunia terhadap indeks harga saham gabungan (studi pada Indonesia periode 2008-2016). Jurnal Administrasi Bisnis, 53(1), 66-74., 53(1), 66-74.

- Investing. (2021). Investing. https://www.investing.com/

- Kontan. (2017). Berita Terkini Investasi dan Ekonomi Indonesia - KONTAN https://www.kontan.co.id/

- Masriyani, M., Mardani, R. M., \& Saraswati, E. (2021). Pengaruh Kurs, Inflasi, Harga Emas Dan Tingkat Suku Bunga Bank Indonesia (BI Rate) 
Terhadap Indeks Harga Saham Gabungan Di BEI Periode 2017-2019. Jurnal Ilmiah Riset Manajemen, 10(3).

- Novianti, W., \& Perwati, A. (2019). Inflation Effects and World Crude Oil Prices on Combined Stock Price Index (CSPI) in Indonesia Stock Exchange (IDX) of 2015-2018 Period. International Conference on Business, Economic, Social Science, and Humanities-Economics, Business and Management Track (ICOBEST-EBM 2019), 81-84.

- Nurwulandari, A. (2021). Kurs Rupiah, Indeks Nikkei 225, BI Rate, dan Pengaruhnya terhadap Stock Exchange Indeks Harga Saham Gabungan (IHSG) Periode Tahun 2018-2020. Akselerasi Jurnal Ilmiah Nasional, 3(1), 75-81.

- OJK. (2019). Otoritas Jasa Keuangan. https://www.ojk.co.id/

- $\quad$ Oktavia, S. H., Utary, A. R., \& Defung, R. (2018). The Effect of Commodity Price on Indonesia Rupiah Exchange Rate and Dow Jones Index on Indonesia Stock Exchange. Jurnal Ekonomi Dan Bisnis Jagaditha, 5(2), 109-118. https://doi.org/10.22225/jj.5.2.809.109-118

- Purnama, M., Hanitha, V., \& Purnama, O. (2021). Pengaruh Harga Emas, Harga Minyak, Kurs Tengah
Bank Indonesia, dan Suku Bunga Acuan Bank Indonesia Terhadap Indeks Harga Saham Gabungan (IHSG)di Bursa Efek IndonesiaPada Periode Juli 2020 -Desember 2020. ECo-Buss, 3(3), 81-94.

- Robiyanto, R. (2018). The Effect of Gold Price Changes, USDIDR Exchange Rate Changes and Bank Indonesia (BI) Rate on Jakarta Composite Index (JCI)'S Return and Jakarta Islamic Index (JII)'S Return. Jurnal Manajemen Dan Kewirausahaan, 20(1), 20(1), 45-52.

- Rosalyn, A. M. (2018). The Effect of Rupiah Exchange Rate and Inflation Rate towards Composite Stock Price Index in Indonesia Stock Exchange. Russian Journal of Agricultural and Socio-Economic Sciences, 78(6).

- Sartika, U. (2017). Pengaruh Inflasi, Tingkat Suku Bunga, Kurs, Harga Minyak Dunia Dan Harga Emas Dunia Terhadap IHSG Dan JII Di Bursa Efek Indonesia. Balance Jurnal Akuntansi Dan Bisnis, 2(2), 285-294.

- Yasar, B., Martin, T., \& Kiessling, T. (2020). An empirical test of signalling theory. Management Research Review, 43(11), 1309-1335. https://doi.org/10.1108/MRR-08-2019-0338. 